\title{
Geospatial and Statistical Assessment of Groundwater Contamination Due to Landfill Leachate-A Case Study
}

\author{
Jaseela Chonattu, Kavya Prabhakar, Harikumar Puthenveedu Sadasivan Pillai \\ Water Quality Division, Centre for Water Resources Development and Management, Kozhikode, India \\ Email: hps@cwrdm.org
}

Received 29 December 2015; accepted 1 February 2016; published 4 February 2016

Copyright (C) 2016 by authors and Scientific Research Publishing Inc.

This work is licensed under the Creative Commons Attribution International License (CC BY).

http://creativecommons.org/licenses/by/4.0/

(c) (i) Open Access

\begin{abstract}
This study was conducted to measure the impact of a municipal solid waste landfill on groundwater quality around Njelianparamba, a solid waste dumping site in Kozhikode district, Kerala state, India. One of the major problems associated with dumping of municipal solid waste landfill is the release of leachate and its impact on surrounding groundwater. In this study, physico-chemical and bacteriological parameters of groundwater samples collected from the region surrounding the leachate area during the pre- and post-monsoon seasons were analysed. The majority of the groundwater samples contained contaminants at a level beyond the permissible limit set by the Bureau of Indian Standards for drinking water quality. The Geographic Information System software of the Environmental Systems Research Institute, (USA) ArcMap 10.1 was used to prepare spatial distribution maps of different parameters and Leachate Pollution Index and Water Quality Index in the study area were applied to assess the overall quality of groundwater. Characterisation of leachate and groundwater samples revealed that, water in the domestic wells has been deteriorated in response to the percolation of leachate. Additionally spatial and correlation analysis revealed that contamination was present maximum within $300 \mathrm{~m}$ radius around the landfill site.
\end{abstract}

\section{Keywords}

Correlation Analysis, Geographic Information System, Leachate, Leachate Pollution Index, Percolation, Water Quality Index

\section{Introduction}

Groundwater has long been considered as an important water source owing to its relatively low susceptibility to

How to cite this paper: Chonattu, J., Prabhakar, K. and Pillai, H.P.S. (2016) Geospatial and Statistical Assessment of Groundwater Contamination Due to Landfill Leachate-A Case Study. Journal of Water Resource and Protection, 8, 121-134. http://dx.doi.org/10.4236/jwarp.2016.82010 
pollution and large storage capacity. Groundwater is comparatively safe and reliable when compared with surface water [1]. However, deterioration of groundwater quality has become a serious problem in recent years. Groundwater is not easily contaminated, but once this occurs it is difficult to remediate. Accordingly, the indiscriminate dumping of municipal solid wastes over vast areas that occurs in developing countries, poses a serious threat to the groundwater quality. In Kerala, groundwater or dug wells are the most reliable water sources and $63 \%$ of the populations depend on groundwater for their drinking, domestic, and agricultural needs [2].

Rapid industrialisation, growing population and changing life style are the root causes of increasing solid waste generation in developing countries. In India, about 0.15 million tones of solid waste are generated daily [3]. Landfills have been identified as one of the major threats to groundwater resources throughout the world [4]. Nevertheless, land filling is the most common method used to dispose municipal solid waste due to its favourable economics [5]. Areas near landfills have a greater possibility of groundwater contamination because of the potential for landfill leachate to infiltrate such system [6]. Therefore, it is important to consider this problem as one of the main environmental concerns in developing countries as it may lead to many adverse impacts in future.

Protection of groundwater is a major environmental issue since the importance of water quality on human health has attracted a great deal of interest in recent years [7]. After waste is disposed at landfills, it undergoes a number of physical, chemical and microbiological changes that leads to the release of a toxic liquid known as leachate, which contains innumerable organic and inorganic compounds. The leachate will continuously migrate through the soil strata, eventually contaminating the groundwater system if no action is taken to prevent this phenomenon [8]. The rate and characteristics of leachate produced depends on many factors such as solid waste composition, particle size, degree of compaction, hydrology of the site, landfill age, moisture and temperature conditions and available oxygen [9].

The pollution potential of a particular landfill can be assessed through various indices. Environmental indices such as the Water Quality Index (WQI) and Leachate Pollution Index (LPI) have been developed to determine the extent of pollution. The potential of leachate from different landfills to contaminate local systems can be evaluated using an index known as LPI [10]. This index values can also be used to determine if a landfill requires immediate remediation. Additionally, the CCME WQI is a very useful and efficient tool for summarization and monitoring data to understand the groundwater quality [11].

\section{Materials and Methods}

\subsection{Study Area}

Njelianparamba, a solid waste dumping site of Kozhikode City, India is situated $9 \mathrm{~km}$ from the city. An average of 200 tonnes of waste per day is dumped in to 18 hectare area. The dumping site is located at $11^{\circ} 13^{\prime} 30^{\prime \prime} \mathrm{N}$ to $11^{\circ} 11^{\prime} \mathrm{N}$ and $75^{\circ} 48^{\prime} \mathrm{E}$ to $75^{\circ} 50^{\prime} 30^{\prime \prime} \mathrm{E}$. The area is one of the primary industrial areas of the Kozhikode district. A number of small, medium and large industrial units on clay, agro-forestry, chemical and metals are located in and around the site. The height of the dump is about 3 to $4 \mathrm{~m}$ above ground level and average of 60 - 80 tonnes of organic waste (vegetable, meat and fish waste) from markets and households are deposited in to the dump daily. The landfill originally accepted only non-hazardous solid wastes but now receives both degradable and non-degradable waste including hazardous waste. Organic solid wastes are treated at the waste treatment plant at Njelianparamba. However, there is no leachate treatment facility in the dump yard. The leachate from the plant and trench yard is collected in a pond on the north east side of the plant.

The study area is characterized by a humid tropical climate with high rainfall. The climate is divided in to four seasons-summer, south west tropical monsoon period (SW), north east tropical monsoon period (NE) and winter. The SW and NE monsoons are responsible for $82.77 \%$ of the total rainfall in the area. June to November is the rainy season in the study area (monsoon season) during which time about $70 \%$ of the rainfall is contributed by the SW monsoon. The average annual rainfall recorded in the area during the study period is $2777 \mathrm{~mm}$ [12]. The mean maximum temperature is $31.67^{\circ} \mathrm{C}$ and the minimum is $22.97^{\circ} \mathrm{C}$. The relative humidity ranges from $74 \%$ to $92 \%$ during morning hours and $64 \%$ to $89 \%$ in evening hours. Physiographically the area lies in the middle portions of the Kozhikode district with an elevation ranging from 15 to $50 \mathrm{~m}$ above the mean sea level. Figure 1 shows the details of Njelianparamba and the sampling locations. 


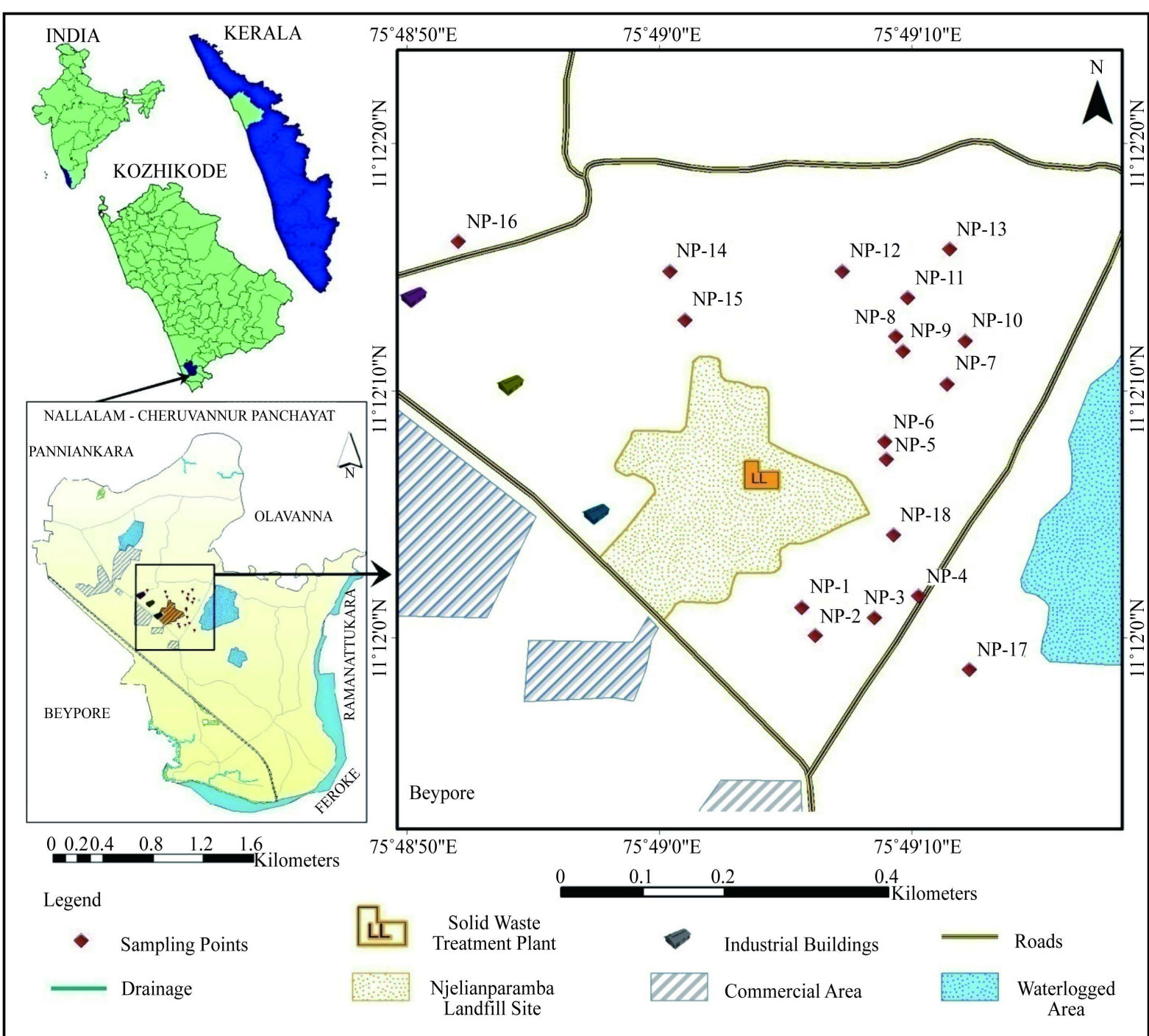

Figure 1. Map of Njelianparamba showing the sampling locations.

\subsection{Hydrogeology}

The geological formations of Njelianparamba primarily consist of porous laterite and forms potential phreatic aquifers; it comes under the midland terrain of Kozhikode district [13]. Lateritic soil is derived from laterite under a tropical climate with alternating wet and dry conditions. The soil is reddish in colour, moderately permeable with an infiltration rate that enables absorption of most of the rain. The $\mathrm{pH}$ of the soil ranges from 5.5 to 6.5 and the texture is sandy loam. Groundwater occurs under phreatic conditions in weathered crystalline rocks and under confined to semi-confined conditions in deeper crystalline formations. Dug wells are the principle water supply for drinking and other purposes in the study area. The average groundwater level during the pre-monsoon period is 2 to $16 \mathrm{mbgl}$ (metres below ground level), whereas the water table level in post-monsoon is 0.38 to 9 mbgl. The effects of leachate percolation are observed in many nearby dug wells in the form of a brown oily appearance and unpleasant foul smell.

\subsection{Sampling and Analysis}

The sampling and analysis of a leachate sample and 18 groundwater samples were conducted during November 2013 (post-monsoon) and May 2014 (pre-monsoon). A random sampling method was used to collect groundwater samples within a $0.5 \mathrm{~km}$ radius of the landfill site and examine its impact on the groundwater quality. The 
samples were collected only from eastern side of the solid waste treatment plant; no well was identified in the western side of the plant. Pre-cleaned polyethylene bottle $(1 \mathrm{~L})$ were used to collect the leachate samples from the drains of the dumping site and groundwater samples from wells around the landfill site. The $\mathrm{pH}$, electrical conductivity and dissolved solids were recorded on site at the time of sampling with a multi-parameter PCSTestr35. To analyze biological oxygen demand (BOD), samples were collected in $300 \mathrm{ml} \mathrm{BOD}$ bottles and dissolved oxygen was fixed onsite (Modified Winkler's method). The total hardness, $\mathrm{Ca}^{2+}, \mathrm{Mg}^{2+}, \mathrm{Cl}^{-}$and total alkalinity were analyzed by titrimetric methods [14]. The $\mathrm{Na}^{+}$and $\mathrm{K}^{+}$concentrations were determined by the Flame Photometric Method while $\mathrm{SO}_{4}^{2-}, \mathrm{PO}_{4}^{2-}$ and $\mathrm{NO}_{3}^{2-}$ were analyzed by UV-VIS Spectrophotometer (Thermo Evolution, USA). The chemical oxygen demand (COD) was measured by open reflux digestion method and BOD was estimated by Azide modification of the Winkler method. For heavy metal analyses (Fe, Zn, $\mathrm{Ni}, \mathrm{Cu}, \mathrm{Pb}$ and $\mathrm{Cd})$, samples were separately collected in to a pre-washed polyethylene containers $(100 \mathrm{~mL})$ and acidified onsite to avoid precipitation of metals, after which they were analyzed using Thermo M5 Series Atomic Absorption Spectrophotometer. The bacteriological analysis (total coliform, faecal coliform and E. coli) was conducted by the Multiple Tube Dilution technique. All chemicals used in this study were of analytical reagent grade and glassware used for analysis was washed with acid solution followed by distilled water. To ensure standard quality control/quality assurance procedures, replicates were analyzed for each sample. Sampling and analysis were conducted according to the Standard Methods for Examination of Water and Wastewater [14].

\subsection{Spatial Interpretation Using Geographic Information System}

The base maps for generating the study maps were collected from the Soil Survey Department of the Kozhikode district. The map of Njelianparamba was digitized and various findings were spatially represented using the ArcMap 10.1 software. A GARMIN GPS was used to record the latitude and longitude of sampling points which were imported into the GIS platform. The interpolation technique, Inverse Distance Weighting (IDW) was used for the spatial modelling of the study results. IDW is an algorithm used to interpolate data spatially or estimate values between measurements. The distribution of total coliform, fecal coliform, E. coli and variations in the dissolved solids with distance from landfill site in groundwater samples of the study area are represented through interpolated GIS maps that were processed by the IDW method.

\section{Results and Discussion}

\subsection{Leachate Characterisation}

The results of physico-chemical analyses of the leachate samples are compared with the National standards set by Ministry of Environment and Forests, Government of India [15] in Table 1. The $\mathrm{pH}$ of leachate was 5.02 to

Table 1. Physico-chemical characteristics of leachate.

\begin{tabular}{cccc}
\hline Parameters & Pre-monsoon & Post-monsoon & Leachate disposal Standard (MoEF 2000) \\
$\mathbf{p H}$ & 5.02 & 4.54 & $5.5-9.0$ \\
$\mathbf{T D S}$ & 16300 & 14300 & 2100 \\
$\mathbf{C h l o r i d e}$ & 8483 & 4954 & 1000 \\
$\mathbf{C O D}$ & 36000 & 34012 & 250 \\
$\mathbf{B O D}$ & 11022 & 10230 & 30 \\
$\mathbf{S O}_{\mathbf{4}}^{2-}$ & 792 & 532 & - \\
$\mathbf{N O}_{3}^{-}$ & 111 & 101 & - \\
$\mathbf{F}^{-}$ & 0.6 & 0.52 & 2 \\
$\mathbf{N a}^{+}$ & 2872 & 2042 & - \\
$\mathbf{K}^{+}$ & 3536 & 3399 & - \\
$\mathbf{F e}$ & 30 & 29 & - \\
$\mathbf{C u}$ & 0.35 & 0.29 & 3 \\
$\mathbf{Z n}$ & 1.6 & 1.4 & 5 \\
$\mathbf{C d}$ & 0.1 & 0.12 & 2 \\
$\mathbf{N i}$ & 1.12 & 1.0 & 3 \\
$\mathbf{P b}$ & 0.23 & 0.22 & 0.1 \\
\hline
\end{tabular}

All values are in $\mathrm{mg} / \mathrm{L}$, except $\mathrm{pH}, \mathrm{EC}$ (in $\mu \mathrm{S} / \mathrm{cm}$ ). 
4.54 in the pre- and post-monsoon seasons respectively, indicating the leachate is acidic in nature. The pre- and post-monsoon dissolved solids were $16300 \mathrm{mg} / \mathrm{L}$ and $14300 \mathrm{mg} / \mathrm{L}$ respectively which were considerably high than the concentration set by the Ministry of Environment and Forests, discharge standard for leachate disposal. The higher value of dissolved solids in the samples is probably due to the large concentration of cations and anions which indicated the presence of inorganic materials. The high BOD and COD indicate the high organic pollution. Leachate contained high levels of chloride that exceed the recommended standards for leachate disposal. Because chloride is inert and non-biodegradable, it can be used as an indicator of contamination [16].

High nitrate concentration is primarily due to domestic waste. The high concentration for sodium and potassium around the landfill indicate impact of leachate. While the high concentration of iron reflects dumping of metal scrap and tin. The color of leachate is dark brown which possibly originated during the oxidation of ferrous to ferric form leading to the formation of ferric hydroxide colloids and compounds with fulvic and humic substances [17]. The presence of $\mathrm{Pb}(0.23 \mathrm{mg} / \mathrm{L})$ in the leachate sample indicate the disposal of lead batteries, chemicals for photograph processing and lead based paints at the landfill site [18]. Cu (0.35 mg/L), Zn (1.6 $\mathrm{mg} / \mathrm{L})$ and $\mathrm{Ni}(1.12 \mathrm{mg} / \mathrm{L})$ were also present in the leachate sample. The pre-monsoon leachate samples showed higher concentration of pollutants than the post-monsoon samples which was attributed to the dilution effect of rain water.

\subsubsection{Leachate Pollution Index}

The LPI (Leachate Pollution Index) provides a proficient method for evaluating extent of leachate pollution from landfill sites. This index is a comparative and quantitative measure of leachate pollution potential that can be efficiently applied to areas prone to leachate migration and subsequent groundwater pollution. To determine the LPI, the sub-index values must be calculated based on the concentration of the leachate pollutants obtained from the sub-index curves for the pollutant variables. The weights for these parameters were calculated based on the significance levels of the individual pollutants. The $\mathrm{p}$ values obtained were multiplied by the respective weights assigned to each parameter to determine the LPI using the Equation (1) [19].

$$
\mathrm{LPI}=\sum_{i=1}^{n} W i P i
$$

where LPI $=$ the weighted additive leachate pollution index, $W i=$ the weight for the $i^{\text {th }}$ pollutant variable, $P i=$ the sub index value of the $i^{\text {th }}$ leachate pollutant variable, $n=$ number of leachate pollutant variables used in calculating LPI

$$
\sum_{i=1}^{n} W i=1
$$

However, if data for all leachate pollutant variables included in LPI is not available, the LPI can be calculated using the dataset of the available leachate pollutants. In such case, the LPI can be calculated by the Equation (2)

$$
\mathrm{LPI}=\frac{\sum_{i=1}^{m} W i P i}{\sum W i}
$$

where $m$ represents the number of leachate pollutant variables for available data, but in that case, $m<18$ and $\sum W i<1$.

The contamination potential of leachate can be calculated in terms of LPI. The calculated LPI of Njelianparamba dumping sites were 28.81 and 25.09 in the pre-and post-monsoon seasons respectively, as given in Table 2. The LPI value at Njelianparamba was higher than its standard value of 7.4 which is the permissible limit for the leachate disposal set by the Municipal Solid Waste Management and Handling Rules, Government of India [15]. The LPI for the two seasons was calculated to determine the seasonal variation in the pollution. Pollution potential values reported during pre-monsoon season indicate that the leachate had polluting potential during pre-monsoon season than the post-monsoon season. Groundwater quality status was lower during the pre-monsoon season, confirming that the pre-monsoon season is more susceptible for pollution potential. The LPI values computed in this study were significantly higher than those reported for other metropolitan cities in India. The LPI value of Pune metropolitan landfill site was 24.67 in pre-monsoon and 19.04 in post-monsoon 
Table 2. LPI in the pre-monsoon (May 2014) and post-monsoon (November 2013) seasons.

\begin{tabular}{|c|c|c|c|c|c|c|c|c|}
\hline \multirow{2}{*}{$\begin{array}{c}\text { Leachate } \\
\text { Constituents }\end{array}$} & \multicolumn{2}{|c|}{ Mean value } & \multicolumn{2}{|c|}{ Individual pollution rating $\mathbf{P i}$} & \multicolumn{2}{|c|}{ Weight Wi } & \multicolumn{2}{|c|}{ Overall pollution rating PiWi } \\
\hline & $\begin{array}{c}\text { Pre- } \\
\text { monsoon }\end{array}$ & $\begin{array}{c}\text { Post- } \\
\text { monsoon }\end{array}$ & $\begin{array}{c}\text { Pre- } \\
\text { monsoon }\end{array}$ & $\begin{array}{c}\text { Post- } \\
\text { monsoon }\end{array}$ & $\begin{array}{c}\text { Pre- } \\
\text { monsoon }\end{array}$ & $\begin{array}{c}\text { Post- } \\
\text { monsoon }\end{array}$ & $\begin{array}{c}\text { Pre- } \\
\text { monsoon }\end{array}$ & $\begin{array}{c}\text { Post- } \\
\text { monsoon }\end{array}$ \\
\hline $\mathbf{p H}$ & 5.02 & 4.54 & 8 & 8 & 0.055 & 0.055 & 0.44 & 0.44 \\
\hline TDS & 16300 & 14300 & 38 & 35 & 0.050 & 0.050 & 1.9 & 1.75 \\
\hline Chloride & 8483 & 4954 & 79 & 40 & 0.048 & 0.048 & 3.79 & 1.92 \\
\hline COD & 36000 & 34012 & 82 & 81 & 0.062 & 0.062 & 5.08 & 5.02 \\
\hline BOD & 11022 & 10230 & 66 & 64 & 0.061 & 0.061 & 4.03 & 3.90 \\
\hline Ammonia Nitrogen & 111 & 101 & 10 & 10 & 0.051 & 0.051 & 0.51 & 0.51 \\
\hline $\mathbf{F e}$ & 30 & 29 & 5 & 5 & 0.045 & 0.045 & 0.23 & 0.23 \\
\hline $\mathbf{C u}$ & 0.35 & 0.29 & 5 & 5 & 0.050 & 0.050 & 0.25 & 0.25 \\
\hline Zn & 1.6 & 1.4 & 5 & 5 & 0.056 & 0.056 & 0.28 & 0.28 \\
\hline $\mathbf{N i}$ & 1.12 & 1.0 & 5 & 5 & 0.052 & 0.052 & 0.26 & 0.26 \\
\hline $\mathbf{P b}$ & 0.23 & 0.22 & 5 & 5 & 0.063 & 0.063 & 0.32 & 0.32 \\
\hline Total & & & & & 0.593 & 0.593 & 17.08 & 14.88 \\
\hline & & & LPI & & & & 28.81 & 25.09 \\
\hline
\end{tabular}

All values are in mg/L except $\mathrm{pH}$.

season [17] and unscientific landfill site in Banglore was 17.1 [20]. These studies concluded that LPI serves as a crucial tool for policy makers and public to identify the pollution threat from landfill. LPI of the leachate shall be treated prior to discharge to meet the leachate disposal standard.

\subsubsection{Physico-Chemical Characteristics of Groundwater Samples}

The physico-chemical composition of groundwater samples in the pre-monsoon and post-monsoon seasons was statistically analyzed and the results provided in Table 3. $40 \%$ of the samples were acidic in nature; and the pH of the water samples varied from 4.76 to 7.68 and 4.36 to 7.13 in the pre- and post-monsoon seasons respectively. The relatively high value of EC and dissolved solids in the samples indicated the presence of inorganic material in both the seasons. The highest dissolved solids were found in the samples collected near the landfill site, indicating that free ions leached from the waste into the groundwater [21]. Of the samples collected, $70 \%$ samples had high dissolved solid levels than the limit prescribed by the Bureau of Indian Standards for drinking water [22]. Temporal changes in dissolved solids during the pre- and post-monsoon seasons are shown in Figure 2. The higher concentration of dissolved solids during the pre-monsoon suggests that the leachate have more pollution potential during pre-monsoon season. COD is a measure of oxygen equivalent to the content of organic matter liable to oxidation with a strong chemical oxidant and thus an index of organic pollution. The concentration of COD ranged from 48 to $264 \mathrm{mg} / \mathrm{L}, 24$ to $220 \mathrm{mg} / \mathrm{L}$ during the pre-and post-monsoon seasons respectively.

\subsubsection{Major Anions in Groundwater}

Groundwater contamination can be traced by considering excess chloride ions as an index of pollution [17] (Kale et al. 2010). Higher concentrations of chlorides were observed in wells close to the dumping site (NP-1, NP-5, NP-6, NP-8, NP-9 and NP-18). The highest value was recorded in well NP-8 which is $106 \mathrm{~m}$ away from the site. Pollution sources such as domestic effluents, fertilizers, and septic tanks, as well as natural source such as rainfall can lead to high $\mathrm{Cl}^{-}$content in groundwater. Sulphate concentrations in the samples were found to range from 40 to $440 \mathrm{mg} / \mathrm{L}$ and 19 to $272 \mathrm{mg} / \mathrm{L}$ in the pre- and post-monsoon seasons respectively. The major sources of nitrate in groundwater include domestic sewage, runoff from agricultural fields and leachate from landfill sites. Drinking water containing more than $45 \mathrm{mg} / \mathrm{L} \quad \mathrm{NO}_{3}^{-}$can cause methamoglobinemia in infants and 
Table 3. Physico-chemical characteristics of groundwater samples: pre- and post-monsoon seasons.

\begin{tabular}{|c|c|c|c|c|c|c|c|c|c|}
\hline \multirow{2}{*}{$\begin{array}{l}\text { Water quality } \\
\text { Parameters }\end{array}$} & \multicolumn{4}{|c|}{ Pre-monsoon } & \multicolumn{4}{|c|}{ Post-monsoon } & \multirow{2}{*}{$\begin{array}{l}\text { Desirable Limit } \\
\text { (BIS 2012) }\end{array}$} \\
\hline & Max & Min & Mean & SD & Max & Min & Mean & SD & \\
\hline $\mathbf{p H}$ & 7.68 & 4.76 & 6.60 & 0.99 & 7.13 & 4.36 & 6.01 & 0.88 & $6.5-8.5$ \\
\hline EC & 1644 & 292 & 939.39 & 418.51 & 1487 & 181 & 621.11 & 305.8 & - \\
\hline TDS & 1170 & 202 & 665.39 & 297.94 & 994 & 130 & 484.44 & 274.79 & 500 \\
\hline $\mathrm{SO}_{4}^{2-}$ & 440 & 44 & 78.26 & 112.28 & 272 & 19 & 64.83 & 67.66 & 200 \\
\hline $\mathrm{Cl}^{-}$ & 620 & 44 & 210.44 & 148.64 & 310 & 3.92 & 197.67 & 96.09 & 250 \\
\hline TA & 357 & 3.40 & 160.18 & 127.02 & 503.23 & 42.58 & 118.50 & 115.17 & 200 \\
\hline TH & 524 & 34.90 & 251.87 & 154.35 & 440 & 44 & 176.22 & 112.28 & 200 \\
\hline $\mathrm{Ca}^{2+}$ & 116 & 9.31 & 55.71 & 34.48 & 164.16 & 6.8 & 47.91 & 44.01 & 75 \\
\hline $\mathbf{M g}^{2+}$ & 84.85 & 0.94 & 27.34 & 22.64 & 38.88 & BDL & 15.43 & 12.54 & 30 \\
\hline $\mathrm{Na}^{+}$ & 294 & 26.0 & 128.56 & 71.74 & 112 & 11.20 & 69.30 & 32.20 & - \\
\hline $\mathbf{K}^{+}$ & 364 & 3.63 & 68.92 & 91.62 & 38.88 & 3.3 & 42.36 & 12.54 & - \\
\hline COD & 264 & 48 & 124.0 & 59.06 & 220 & 24 & 100.0 & 56.46 & - \\
\hline $\mathrm{NO}_{3}^{-}$ & 95.63 & 1.35 & 27.42 & 23.06 & 83 & BDL & 21.50 & 0.88 & 45 \\
\hline $\mathrm{Fe}$ & 0.67 & BDL & 0.15 & 0.42 & 0.52 & BDL & 0.08 & 0.23 & 0.30 \\
\hline $\mathrm{Cu}$ & 0.04 & BDL & 0.011 & 0.02 & 0.59 & BDL & 0.12 & 0.19 & 0.05 \\
\hline Zn & 0.22 & BDL & 0.06 & 0.04 & 0.03 & BDL & 0.0 & 0.01 & 5.0 \\
\hline Mn & 0.23 & 0.03 & 0.07 & 0.06 & 0.18 & BDL & 0.05 & 0.07 & 0.10 \\
\hline Cd & 0.02 & BDL & 0.01 & 0.003 & 0.004 & BDL & 0.001 & 0.003 & 0.003 \\
\hline
\end{tabular}

All values are in $(\mathrm{mg} / \mathrm{L})$ except $\mathrm{EC}(\mu \mathrm{S} / \mathrm{cm})$ and $\mathrm{pH}, \mathrm{BDL}-$ Below Detection Limit.

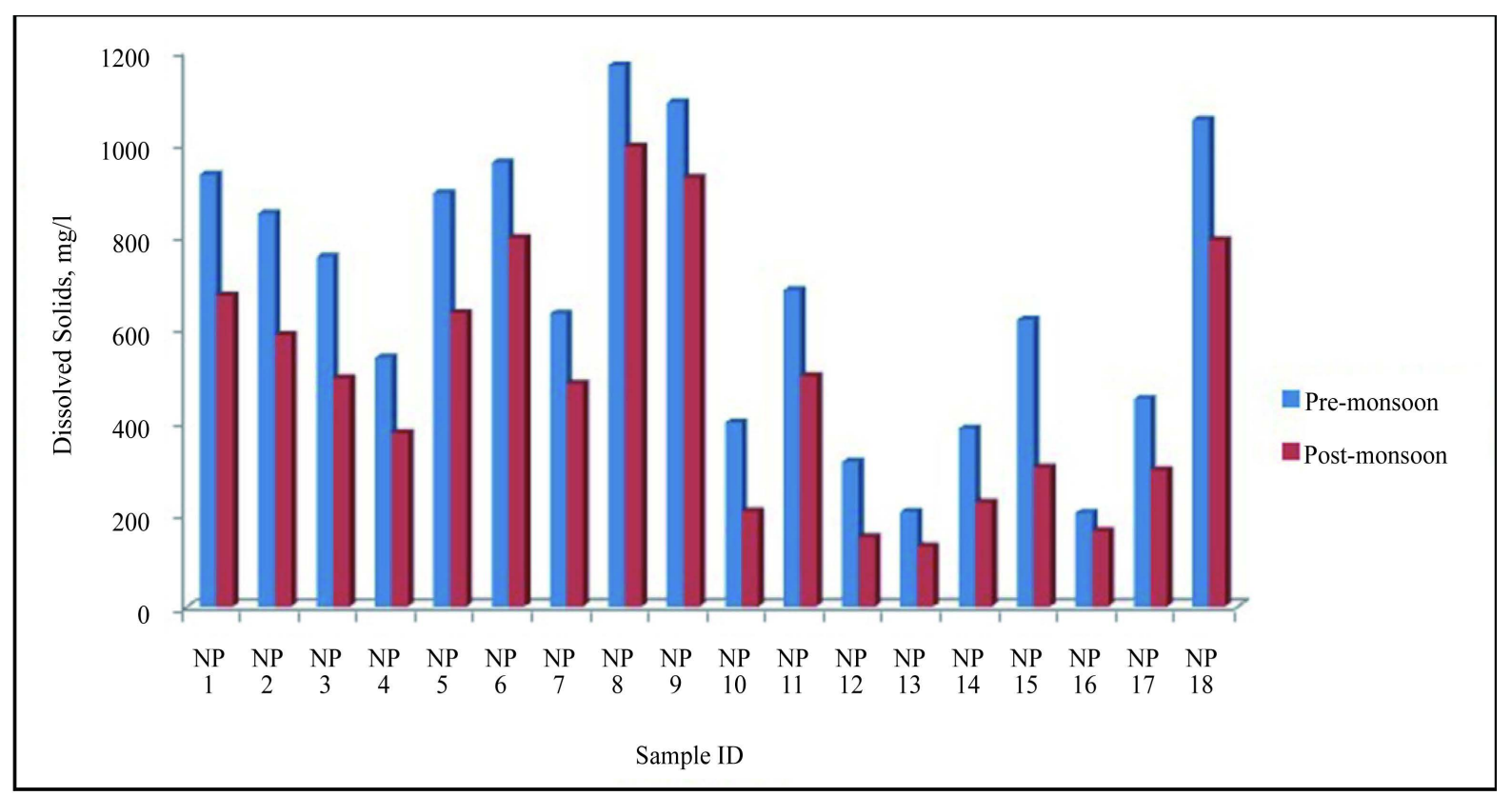

Figure 2. Variations in dissolved solids in pre-monsoon and post-monsoon seasons. 
gastric carcinomas [23] [24]. The nitrate concentrations exceeded the desirable limit at three locations. Nitrate concentration in groundwater samples is attributed to dumping of organic waste at landfill site [25].

\subsubsection{Major Cations in Groundwater}

Almost all samples contained concentration of major cations exceeding their limits. The hardness of samples was found to range from 35 to $524 \mathrm{mg} / \mathrm{L}$ and 44 to $440 \mathrm{mg} / \mathrm{L}$ in the pre- and post-monsoons, respectively. Most of the sample stations reported hardness values exceeding the maximum desirable limit of $200 \mathrm{mg} / \mathrm{L}$ prescribed by BIS. High levels of hardness may affect water supply system resulting in excessive soap consumption, calcification of arteries and cause urinary concretions, diseases of kidney bladder and stomach disorder [26]. $\mathrm{Ca}^{2+}$ and $\mathrm{Mg}^{2+}$ are important ions influencing total hardness. Calcium ranged from 9 to $164 \mathrm{mg} / \mathrm{L}$ with an average value of $55.71 \mathrm{mg} / \mathrm{L}$ for pre-monsoon samples and 6.8 to $164 \mathrm{mg} / \mathrm{L}$ with an average value of $47.91 \mathrm{mg} / \mathrm{L}$ for post-monsoon samples. The permissible limit of calcium ion concentration in groundwater is $75 \mathrm{mg} / \mathrm{L}$ [22]. The concentration of $\mathrm{Mg}^{2+}$ ions ranged from 0.94 to $84 \mathrm{mg} / \mathrm{L}$ and BDL to $38.88 \mathrm{mg} / \mathrm{L}$ in the pre- and post-monsoon seasons, respectively. The permissible limit of magnesium ion in groundwater is $30 \mathrm{mg} / \mathrm{L}$ according to the BIS. Sodium ranged from 26 to $249 \mathrm{mg} / \mathrm{L}$ and 11.20 to $112 \mathrm{mg} / \mathrm{L}$ in the pre- and post-monsoon seasons, respectively. The occurrence of sodium above acceptance levels in wells closest to the landfill indicates possible leachate flow into groundwater [27]. Higher concentrations of potassium were found in well samples in the pre-monsoon than post-monsoon season.

\subsubsection{Heavy Metals in Groundwater}

The groundwater samples were analysed for $\mathrm{Cu}, \mathrm{Fe}, \mathrm{Mn}, \mathrm{Cd}$ and $\mathrm{Zn}$. Iron levels in the groundwater ranged from BDL to $0.67 \mathrm{mg} / \mathrm{L}$ and 0.52 to BDL in the pre- and post-monsoon seasons, respectively. The concentration of iron exceeded in $61 \%$ of the samples collected from the study area. $\mathrm{Cu}$ and $\mathrm{Zn}$ were found to be within the permissible limit prescribed by the BIS. The concentration of Mn exceeded the limit in the sample collected from NP-8, NP-9 and NP-18. The Cd concentrations of the sample were ranged from BDL to $0.02 \mathrm{mg} / \mathrm{L}$ and BDL to $0.004 \mathrm{mg} / \mathrm{L}$ in the pre- and post-monsoon seasons, respectively.

\subsubsection{Spatial Distribution of Bacteria in the Groundwater Sources}

The bacteriological analysis of the groundwater quality was spatially represented and analysed in the form of GIS maps. The distribution of bacteria and the distance between the well and landfill site were the two major criteria used to prepare the maps. The distribution of total coliform, fecal coliform and E. coli bacteria was represented through interpolated GIS maps that were processed by the Inverse Distance Weighting (IDW) method. As shown in Figure 3, 39\% of the total samples analyzed were contaminated with a very high count of total coliform $(\geq 2400)$. Similarly, 33\% of the total samples analyzed were contaminated with fecal coliform ( $\geq 2400$ ), (Figure 4). As shown in Figure 5, 44\% of the samples were contaminated with E. coli. All well samples were grossly contaminated with bacteria with the highest concentration being observed in wells close to the dumping site. The results also demonstrate that large amounts of organic matter were present in groundwater samples caused by leachate percolation which provided nutrients for microbial growth.

\subsubsection{CCME Water Quality Index}

The Canadian Council of Ministers of the Environment introduced an index to determine water quality (CCME WQI). This index provides a suitable method to aggregate a complex water quality data that can be understood easily by the public, policy makers, planners and water distributors [28]. CCME WQI includes three elements: scope (F1), the number of water quality variables not meeting the water quality objective; frequency (F2), the number of times, objectives are not met and amplitude (F3), the degree to which objectives are not met. The CCME WQI is calculated using the Equation (3)

$$
\text { CCMEWQI }=100-\frac{\sqrt{F_{1}^{2}+F_{2}^{2}+F_{3}^{2}}}{1.732}
$$

The factor of 1.732 has been introduced to scale the index from 0 to 100 , where zero signifies very poor water quality and values close to 100 signify excellent water quality. The water quality is ranked in the following five categories shown below. A WQI map was created using the CCME WQI classification to understand the groundwater quality. 


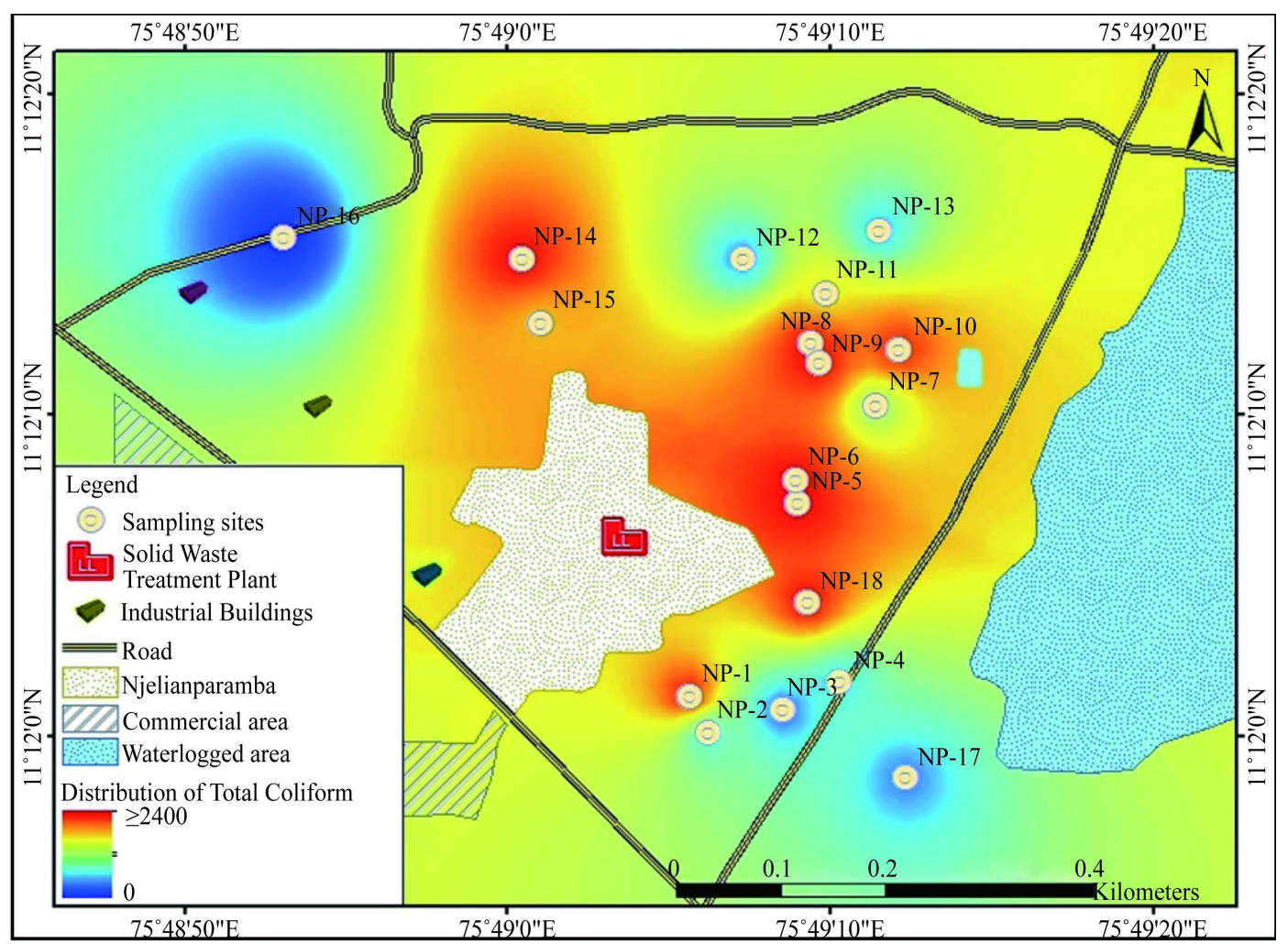

Figure 3. Distribution of total coliforms in groundwater samples.

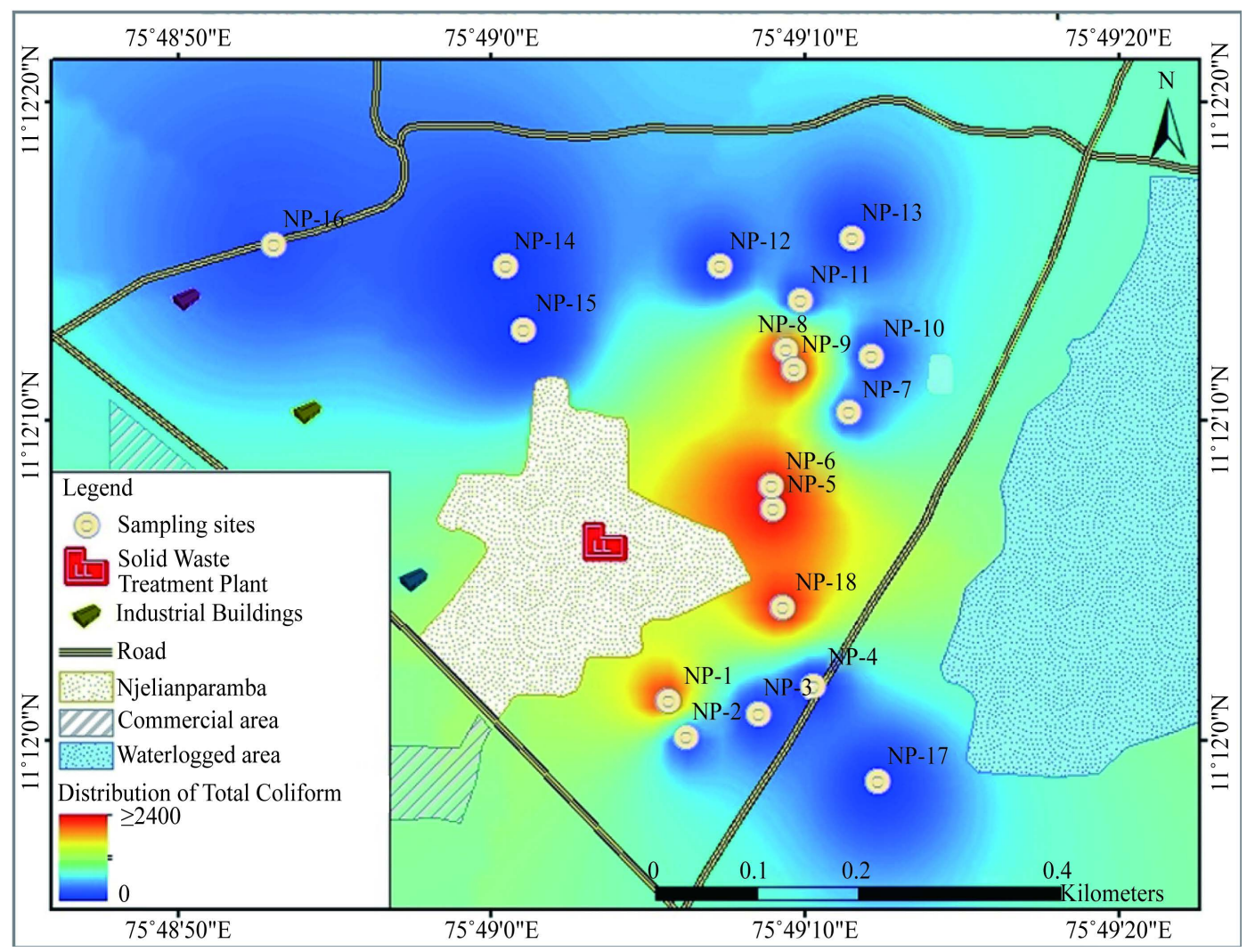

Figure 4. Distribution of fecal coliforms in groundwater samples. 


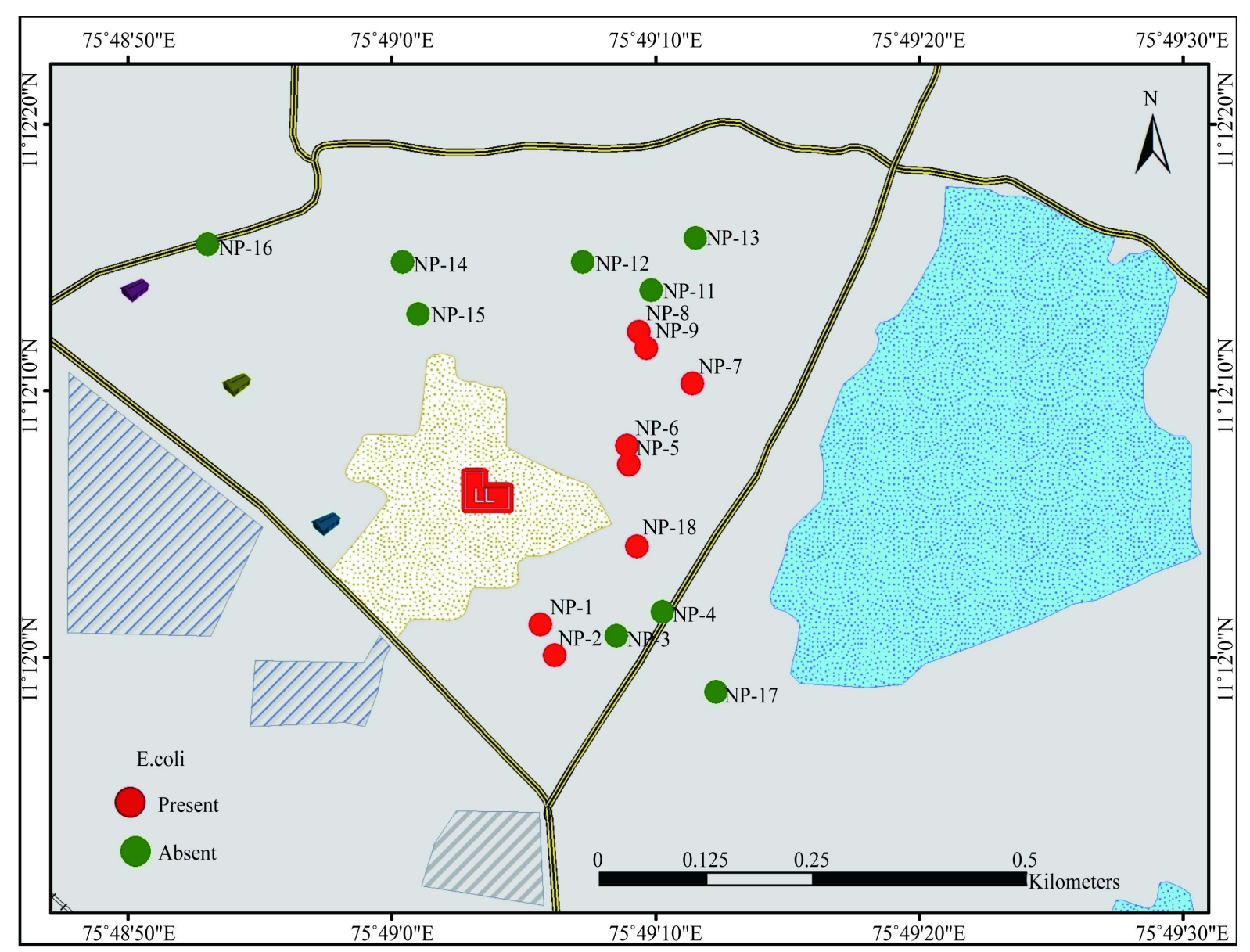

Figure 5. Distribution of E. coli in groundwater samples.

Excellent: (CCME WQI values 95 - 100)

Good: (CCME WQI values 80 - 94)

Fair: (CCME WQI values 60 - 79)

Marginal: (CCME WQI values 45 - 59)

Poor: (CCME WQI values 0 - 44)

\subsubsection{Spatial Distribution of CCME WQI in the Groundwater Sources}

The overall water quality in the study area was represented using CCME WQI. CCME WQI of the study area was calculated in the pre- and post-monsoon seasons. According to CCME WQI, six sampling sites (NP-1, NP-5, NP-6, NP-8, NP-9 and NP-18) showed poor WQI values. All the six sites were located $200 \mathrm{~m}$ from the dumpsite. Additionally, eight sites showed marginal water quality and four stations showed fair water quality. A CCME WQI map was created using the CCME WQI classification to understand the groundwater quality in the study area. Figure 6 explains the three classes of water quality in the study area. GIS-based spatial analysis techniques have been shown to be a powerful tool to represent water quality assessed by CCME WQI values. Analysis using this method suggests that the majority of the sites in this study area falls had poor and marginal category. The spatial distribution map clearly showed that portions of the study area close to the landfill had poor groundwater quality. Figure 6 represents the spatial distribution of CCME WQI in groundwater.

\subsubsection{Impact of Distance from Landfill on Solid Waste Leachate}

The spatial variation of the dissolved solids in groundwater samples and distances from the landfill to the study area were represented using Geographic Information System. Samples were collected spatially at different distances from the landfill site. These two criteria were used to determine the groundwater quality at the sampling 


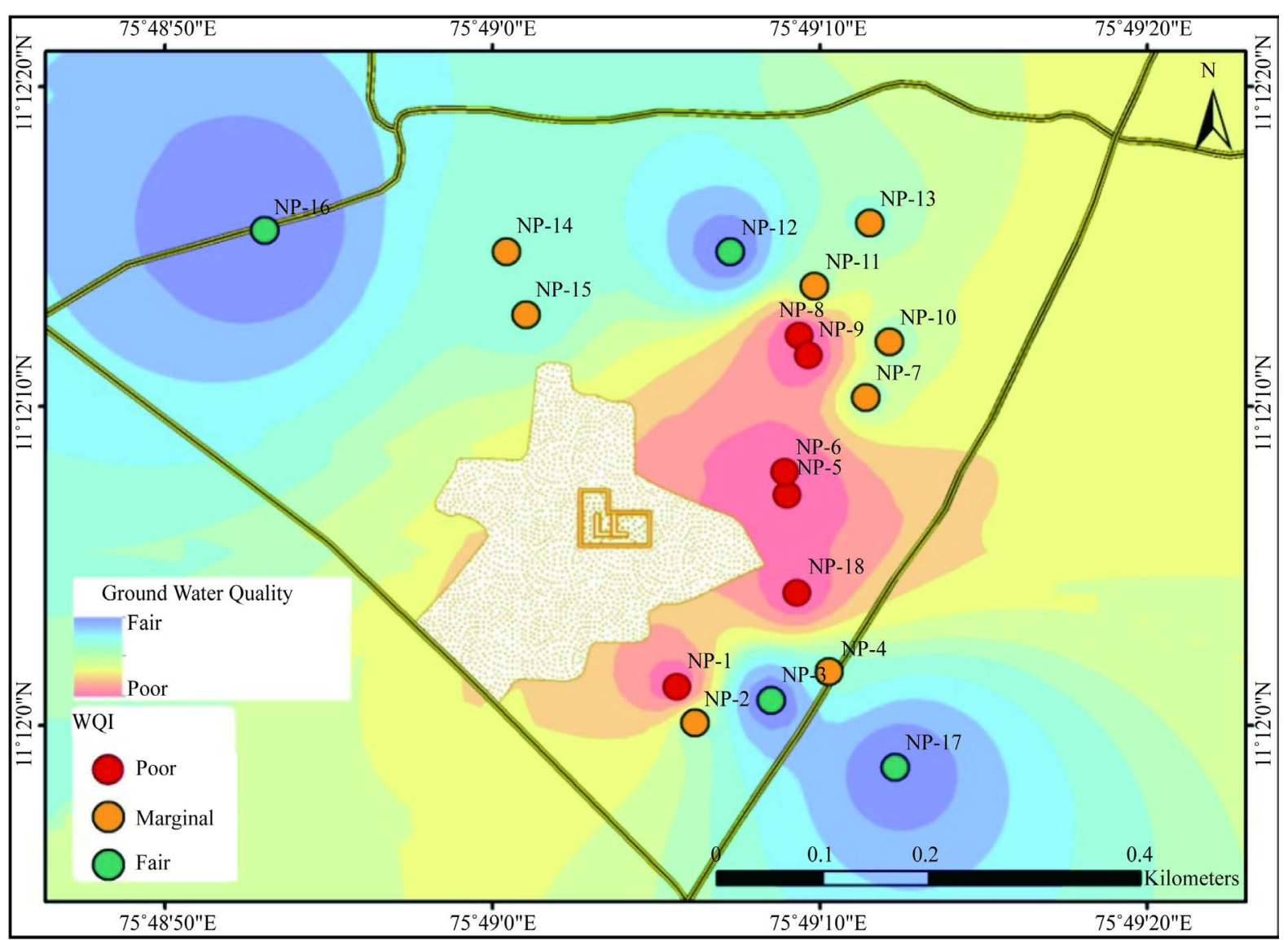

Figure 6. Spatial distribution of CCME WQI in Njelianparamba.

sites with proximity to the landfill. Figure 7 represents the variation of Total Dissolved Solids (TDS) with distance from the landfill site. The total sampling sites were grouped into three buffer zones based on the TDS concentration. Buffer zone I, which contained most of the sampling sites, corresponds to the distance of 0 - 200 $\mathrm{m}$ from the landfill. Sites in zone I included; NP-1 to NP-9, NP-12, NP-14, NP-15 and NP-18. The TDS values of these sites were high, indicating that the water is unfit for any use. Zone II was 200 to $300 \mathrm{~m}$ from the landfill site. Although it is not as hazardous as Zone I, use of water from these sites is not recommended. Zone III consisted of 300 - $500 \mathrm{~m}$ from the landfill.

Groundwater samples from this zone had low TDS. The zonation map showed that the sampling sites within zone I and II contain more soluble salts in groundwater and cannot be used for any purpose. As shown in Figure 7, samples from wells situated close to the landfill site were found to be more heavily contaminated than those located far away. These findings indicate that the gravitational movement of the leachate is hindered by the mass of the soil matter. Over increasing time, the viscous fluid may penetrate deeper and spread all over a longer distance.

\subsubsection{Correlation Analysis}

Correlation analysis is a descriptive technique to assess the degree of association among variables. Statistical package for Social Sciences (SPSS version 19.0) was used for correlation analysis. In this study, Pearson correlation coefficients were determined for various water quality parameters.

Table 4 shows the Pearson's correlation matrix between the two parameters (TDS and chloride) and their well depth and distance from the landfill site. Chloride is a useful tracer of groundwater contamination (Mor et al. $2006)$ and TDS is a valuable index of total ions in samples. Strong negative correlations $(-0.863$ and -0.733$)$ were obtained for the concentrations of TDS and chloride respectively with their distance from the landfill site. The significant negative correlation for TDS with distance from the dumpsite shows that the concentration of 


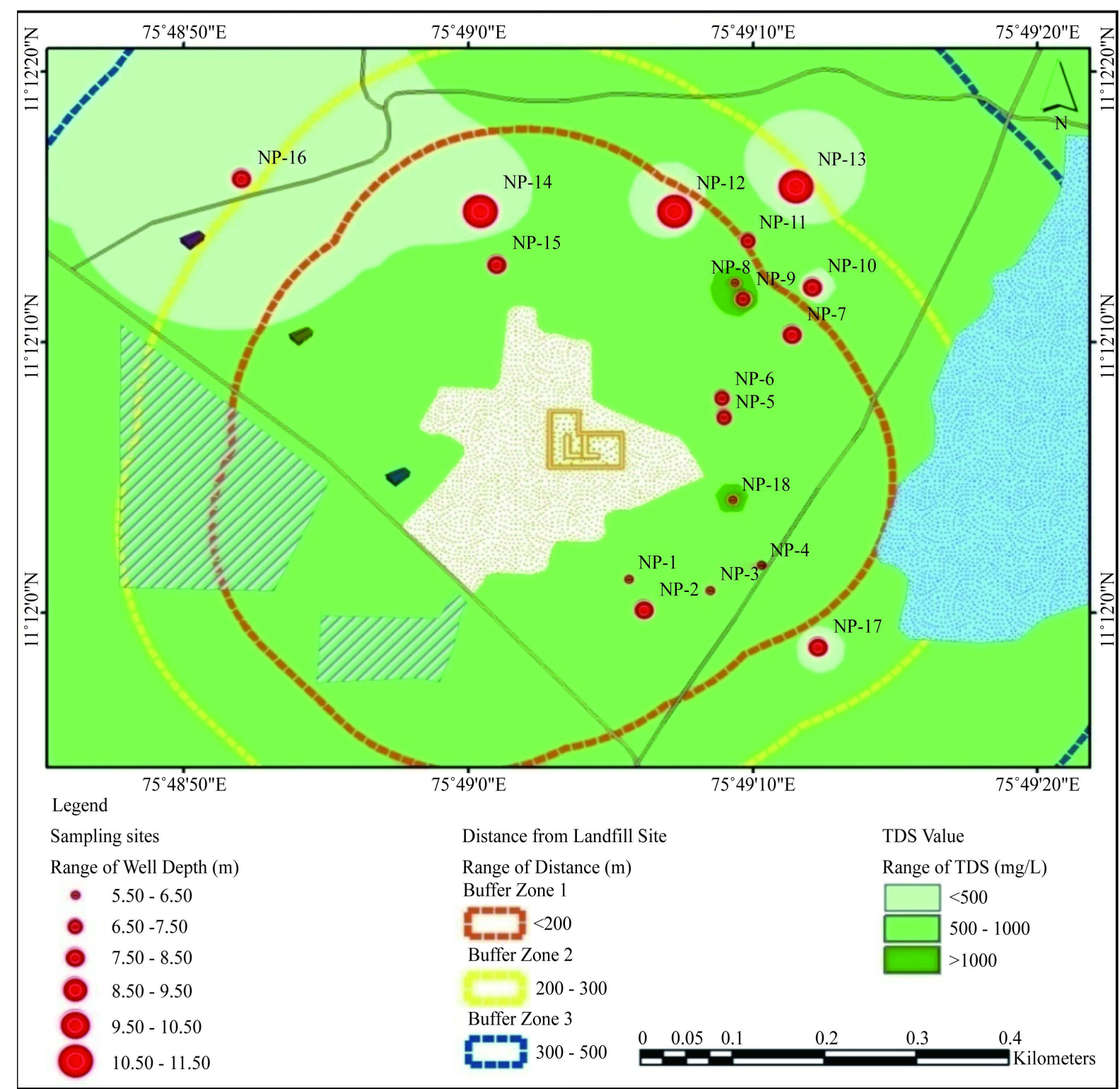

Figure 7. Variation of TDS with distance from landfill site.

Table 4. Correlation coefficient for different parameters.

\begin{tabular}{cccc}
\hline Parameters & Distance & Depth & TDS \\
\hline Distance & 1.0 & 0.416 & -0.863 \\
Depth & 0.416 & 1.0 & -0.510 \\
TDS & -0.863 & -0.510 & 1.0 \\
Chloride & -0.733 & -0.516 & 0.854 \\
\hline
\end{tabular}

Correlation $> \pm 0.6$ are in italics.

contaminants in groundwater normally decreases with increasing distance from pollution. A moderately high negative correlation was obtained for TDS and chloride with well depth, which also indicated that the concentration of contaminants in groundwater samples decreased with increasing depth. Correlation analysis confirmed that groundwater quality improved with increases in well depth and the distance of the well from the pollution 
source.

\section{Conclusion}

The impact of landfills leachate on the surrounding groundwater quality in Njelianparamba, India is a major environmental concern of the area. In this study, physico-chemical and bacteriological parameters of leachate and groundwater samples collected in and around the landfill site were analysed. The results showed that the wells in close proximity to the landfill (NP-5, NP-6, NP-8, NP-9 and NP-18) were most affected by leachate percolation. Spatial distribution of groundwater quality parameters was measured by GIS. LPI and WQI in the study were applied to assess the overall quality of the leachate and groundwater. This method appears to be more systematic and provides a comparative evaluation of the quality of sampling sites. The LPI value at Njelianparamba for both the seasons exceeded the standard LPI of 7.4 proposed for leachate disposal. CCME WQI map was also generated using the same technique to understand the water potability spatially. The CCME WQI indicted that majority of the study area had poor and marginal water quality. However, the quality improved with increase in distance of the well from the pollution source. The majority of the parameters showed an inverse relationship between concentration and distance. The results of this study indicated that the Njelianparamba municipal dumping site was prone to groundwater contamination through leaching. Because dumping is a continuous process, without proper treatment facilities, groundwater in the surrounding area will gradually become more adversely by this activity.

\section{References}

[1] Gupta, N. (2014) Groundwater Vulnerability Assessment Using DRASTIC Method in Jabalpur District of Madhya Pradesh. International Journal of Recent Technology and Engineering, 3, 36-43.

[2] Census of India (2011) Main Sources of Drinking Water 2001-2011. Department of census Kerala, Ministry of Home Affairs, New Delhi.

[3] Rathod, M., Mishra, H. and Karmakar, S. (2013) Leachate Characterization and Assessment of Water Pollution near Municipal Solid Waste Landfill Site. International Journal of Chemical and Physical Science, 2,186-189.

[4] USEPA (United States Environmental Protection Agency) (1984) A groundwater protection strategy for the Environmental Protection Agency. EPA Number: 440684002.

[5] Wijesekara, S.S.R.M.D.H.R., Mayakaduwa, S.S., Siriwardana, A.R., de Silva, N., Basnayake, B.F.A., Kawamoto, K. and Vithanage, M. (2014) Fate and Transport of Pollutants through a Municipal Solid Waste Landfill Leachate in Sri Lanka. Environmental Earth Sciences, 72, 1707-1719. http://dx.doi.org/10.1007/s12665-014-3075-2

[6] Nagarajan, R., Thirumalaisamy, S. and Lakshumanan, E. (2012) Impact of Leachate on Groundwater Pollution Due to Non-Engineered Municipal solid Waste Landfill Sites of Erode City, Tamil Nadu, India. Iranian Journal of Environmental Health Sciences \& Engineering, 9, 35. http://dx.doi.org/10.1186/1735-2746-9-35

[7] Akinbile, C.O. and Yusoff, M.S. (2011) Environmental Impact of Leachate Pollution on Groundwater Supplies in Akure, Nigeria, International Journal of Environmental Science and Development, 2, 81-86. http://dx.doi.org/10.7763/ijesd.2011.v2.101

[8] Kanmani, S. and Gandhimathi, R. (2013) Assessment of Heavy Metal Contamination in Soil Due to Leachate Migration from an Open Dumping Site. Applied Water Science, 3, 193-205. http://dx.doi.org/10.1007/s13201-012-0072-z

[9] Jhamnani, B. and Singh, S.K. (2009) Groundwater Contamination Due to Bhalaswa Landfill Site in New Delhi. International Journal of Civil and Environmental Engineering, 1, 121-125.

[10] Kumar, D. and Alappat, B.J. (2003) A Technique to Quantify Landfill Leachate Pollution. Proceedings of the 9th International Landfill Symposium, Cagliari, 6-10 October 2003, Paper No. 400.

[11] Selvam, S., Manimaran, G., Sivasubramanian, P., Balasubramanian, N. and Seshunarayana, T. (2013) GIS-Based Evaluation of Water Quality Index of Groundwater Resources around Tuticorin Coastal City, South India. Environmental Earth Sciences, 71, 2847-2867. http://dx.doi.org/10.1007/s12665-013-2662-y

[12] IMD (2013) Normal South West Monsoon Rainfall Data. Indian Meteorological Department, Kozhikode District, Kerala.

[13] CGWB (2009) Groundwater Information Booklet of Kozhikode District, Kerala State. Central Ground Water Board, Ministry of Water Resources, Government of India.

[14] APHA, AWWA, WEF (2012) Standard Methods for Examination of Water and Waste Water. 22nd Edition, American Public Health Association, Washington DC. 
[15] MoEF (2000) Municipal Solid Waste Management and Handling Rules. Notification Issued by Ministry of Environment and Forests, Government of India.

[16] D’Souza, O. and Somashekar, R.K. (2012) Pollution Potential of Leachate from an Unscientific Landfill and Its Impact on Groundwater. Electronic Journal of Environmental Science, 5, 21-32.

[17] Kale, S.S., Kadam, A.K., Kumar, S. and Pawar, N.J. (2010) Evaluating Pollution Potential of Leachate from Landfill Site from the Pune Metropolitan City and Its Impact on Shallow Basaltic Aquifers. Environmental Monitoring Assessment, 162, 327-346. http://dx.doi.org/10.1007/s10661-009-0799-7

[18] Mor, S., Ravindra, K., Dahiyaa, R.P. and Chandra, A. (2006) Leachate Characterization and Assessment of Groundwater Pollution near Municipal Solid Waste Landfill Site. Environmental Monitoring Assessment, 118, 435-456. http://dx.doi.org/10.1007/s10661-006-1505-7

[19] Kumar, D. and Alappat, B.J. (2005) Evaluating Leachate Contamination Potential of Landfill Sites Using Leachate Pollution Index. Clean Technology and Environment, 7, 190-197. http://dx.doi.org/10.1007/s10098-004-0269-4

[20] D’Souza, P. and Somashekar, R.K. (2013) Assessment of Stabilization, Temporal Variation and Leachate Contamination Potential of Municipal Solid Waste Dumpsites in Bangalore. International Journal of Environmental Protection, 3 , 28-35.

[21] Dharmarathne, N. and Gunatilake, J. (2013) Leachate Characterization and Surface-Groundwater Pollution at Municipal Solid Waste Landfill of Gohagoda, Sri Lanka. International Journal of Scientific Research, 3, 1-7.

[22] BIS (2012) Indian Standard Drinking Water Specification. Bureau of Indian Standards, New Delhi.

[23] Hopps, H.C. and Feder, G.L. (1986) Chemical Qualities of Water That Contribute to Human Health in a Positive Way. Science of the Total Environment, 54, 207-216. http://dx.doi.org/10.1016/0048-9697(86)90266-4

[24] Jalali, M. (2005) Nitrate Pollution of Groundwater in Toyserkan. Western Iran Environmental Earth Science, 62, 907913. http://dx.doi.org/10.1007/s12665-010-0576-5

[25] Kathale, N. (2012) Physico-Chemical Status of the Groundwater of Southeastern Area, Chandrapur, Maharashtra, India. International Journal of Interdisciplinary Research, 2, 165-172.

[26] CPCB (2008) Guideline for Water Quality Management. Central Pollution Control Board, Delhi. http://www.cpcb.nic.in.

[27] Adeolu, A.O., Ada, O.V., Gbenga, A.A. and Adebayo, O.A. (2011) Assessment of Groundwater Contamination by Leachate near a Municipal Solid Waste Landfill. African Journal of Environmental Science and Technology, 5, 933940.

[28] CCME (2001) Canadian Water Quality Guidelines for the Protection of Aquatic Life: CCME Water Quality Index 1.0 Technical Report. Canadian Council of Ministers of the Environment, Winnipeg. http://www.ccme.ca/files/Resources/calculators/WQI\%20User's\%20Manual\%20(en).pdf 